\title{
Research on the Practical Teaching Mode of Environmental Design Based on the "Integrated" Educational Whole Value Chain
}

\author{
Dong Rui \\ School of Culture Communication \& Design, Zhejiang University of Finance \& Economics Dongfang College, Hangzhou, China
}

\section{Email address:}

dongxiaoyaya@126.com

\section{To cite this article:}

Dong Rui. Research on the Practical Teaching Mode of Environmental Design Based on the "Integrated" Educational Whole Value Chain. International Journal of Education, Culture and Society. Vol. 6, No. 2, 2021, pp. 63-70. doi: 10.11648/j.ijecs.20210602.14

Received: April 8, 2021; Accepted: April 21, 2021; Published: April 29, 2021

\begin{abstract}
This project is based on the concept of "Maker Education" of the integration of innovation education, experiential education, project-based learning, application of science and technology, and the cultivation of students' practical ability. The content setting of the practical innovation of the environmental design major of Zhejiang University of Finance \& Economics Dongfang College is not deep enough, and the teaching philosophy and students' practice mode cannot adapt well to the current development situation. To tackle these problems, based on the analysis of the theoretical and practical research status of "Maker Education" at home and abroad, this project carries out the environmental design of the "Integrated" practical teaching reform exploration. By optimizing the environmental curriculum system, this paper aims to construct a practical curriculum system around the "integrated $1+2+2$ ", thereby expanding the original practical teaching mode to a three-dimensional one; In this way, it can resolve existing problems in detail from macro, meso, and micro levels. Through the three-dimensional derivation and expansion of the practical teaching mode of the original curriculum system, the connotation of the "integrated" practical teaching is transformed into the value-added education of knowledge and skills. And it provides a reference for optimizing and upgrading the construction of the application-oriented profession of environmental design. Finally, the training goal of practical teaching runs through daily learning to form a trend of integrating practical education into the whole process of university personnel training.
\end{abstract}

Keywords: Talent Cultivation, Integration, Maker Education, Practical Teaching, Environmental Design

\section{Introduction}

In recent years, with the transformation and upgrading of China's economic structure and the continuous upgrading and adjustment of the industrial structure, the demand for innovative practice and applied talents has been increasing [1]. Nowadays, when it comes to practice teaching, the spirit of double creation is often mentioned. In the 2015 government work report, Premier Li Keqiang emphasized the importance of innovation and entrepreneurship for a country's development in the modern era. Later in the same year, innovative design was included in the list of Made in China 2025 strategic plan. Since 2016, Maker Education has entered a great developing period; in January 2017, the Ministry of Education issued the Implementation Measures for Promoting World-Class University and First-Class
Discipline Construction, in which innovation and entrepreneurship achievements were listed as selection standards [2]. Under the background of mass entrepreneurship and innovation, great challenges are brought into the education of environmental design major in applied universities. As a relatively young major, Zhejiang University of Finance \& Economics Dongfang College' s environmental design major is currently faced with problems such as imperfect professional curriculum system, insufficient in-depth setting of practical innovation content, and poor adaptation of teaching concepts and student practice models to the development of the time. The main purpose of this paper is to optimize the curriculum system of this major to construct a practical teaching mode of environmental design in the whole value chain of integrated education. How to integrate practical application and 
innovation and entrepreneurship into teaching is of great significance and importance to the exploration of the curriculum system and research on talent cultivation of design discipline.

\section{Research Status and Development Trends at Home and Abroad}

The integrated practical teaching mode of environmental design refers to the derivation of the singleness of previous professional knowledge education, which organically combines professional knowledge and innovative education mode with compound and entrepreneurial education mode, so as to tap the potential of education, having much in common with the maker education in universities [3]. The "integrated" educational whole value chain discussed in this article is a further upgraded type based on that. The development status of Maker Education at home and abroad is analyzed as follows, so as to make preparations for further discussion on the construction of environmental design teaching system.

\subsection{Theoretical Research}

After research on relevant domestic and foreign documentary data, this paper chose Professor Zhu Zhiting from East China Normal University and American scholars Sylvia Libow Martinez and Gray S. Stager as references to explain Maker Education.

Through literature research and review, it can be found that Maker Education incorporates various elements in concepts of experiential education, project-based learning, innovation education, and DIY [4]. Specifically, it can be summarized as below: First, Maker Education places great emphasis on practice, attaching importance to the sense of deep participation in experience education; second, maker education, centered on a specific task, enables students to learn in group cooperation, thereby developing students' ability to solve practical problems [5]; third, inheriting the concept of innovation education, Maker Education aims to cultivate students' innovative consciousness, thinking and ability; fourth, Maker Education incorporates a new factor into it, that is, science and technology, which have become an indispensable part. Besides, the DIY concept is also integrated, so as to cultivate students' craftsmanship spirit [6].

To sum up, Maker Education regards learning based on creation or learning in creation as the learning method students really need. In Maker Education, students are no longer passive receivers and consumers of information and knowledge, but active knowledge applicators and creators [7]; teachers need to think about ways to abandon traditional teaching methods and thinking methods which tend to put students in a passive position, and rethink methods to truly respect the subjectivity and initiative of students, in order to develop students' creativity and enhance their ability to use technology and methods so as to creatively solve practical problems [8].

\subsection{Practice Research}

In terms of the current development of practice teaching in Chinese universities, maker education mainly derives from the following two points: First, under the background of new technological and industrial revolutions, maker education has been promoted thanks to the interaction between the international maker movement and the global education reform, thereby becoming an important orientation in the current education reforms of all countries in the world; Second, with mass entrepreneurship and innovation burgeoning, focus on the reform of innovation and entrepreneurship education in colleges and universities will effectively promote the close integration of higher education and technology, economy, and society, thereby accelerating training for a great number of innovative and entrepreneurial talents with innovative spirit and courage to devote themselves to practice.

Nowadays, Chinese colleges and universities have systematically carried out maker education by optimizing resources, integrating different majors, targeting innovation, and taking into account entrepreneurship. Besides, they also have established an unique, innovation and entrepreneurship education system centered on maker development through the innovation and integration of different elements such as institutional mechanisms, institutions, models, courses and teaching. Among them, the maker education developed by Renmin University of China is an interdisciplinary and comprehensive one, which emphasizes the cultivation of maker spirit and the accumulation of maker culture with importance attached to procedural and divergent training practice; Shanghai University of Finance and Economics cultivates first-class innovative and entrepreneurial talents and young creators with the core literacy of innovation and entrepreneurship as a breakthrough; Zhongnan University of Economics and Law includes entrepreneurship education training goals into the overall talent cultivation goals of the university, showing a tendency to integrate entrepreneurship education into university talent training; Ningxia University explores the constituent elements and practice of the university maker education ecosystem from the perspective of ecological system theory; meanwhile, Heilongjiang University, Shandong University of Technology, Wenzhou University, Zhejiang University of Science and Technology are all exploring the university maker education [2].

To sum up, although the maker education practice mentioned above is of certain reference significance to environmental design majors, how to systematically conduct "integrated" educational whole value chain practical teaching mode needs further exploration for environmental design, a major that is originally practical.

\subsection{The Status Quo and Trend of Domestic and Foreign Research on Practice Teaching of Environmental Design}

In 2012, the Ministry of Education issued a new edition of College and University Undergraduate Catalogue, in which art majors were included. The recognition of design as a 
first-level discipline not only represents the recognition of design in the education circle, but also sets a higher demand for design education in the transformation of modern society.

The design education model of internationally renowned universities provide references for curriculum reform of design discipline, including Coventry University in the United Kingdom, Carnegie Mellon University in the United States and the University of Cincinnati. Many adjustments and reforms have been made to the traditional education system, such as curriculum settings, teaching methods, and curriculum management. In the reform process, in addition to learning from other disciplines, such as sociology and humanities, carrying out interactive research with enterprises to cultivate students' ability to discover, analyze and solve problems is also important [9]; Besides, Stanford University, a pioneer in maker education, effectively combines entrepreneurship, innovation, education, society and business, emphasizing interdisciplinary, people-oriented, and student-centered experiential education concept. The curriculum setting models of foreign universities mentioned above all provide reference for the design education in China.

\subsection{Conclusion}

In summary, in terms of the professional characteristics, the development status at home and aboard and relevant data analysis, the current maker education in China is still at a supplementary stage to the existing education system, lacking integration with the existing education system; What's more, how to integrate the practical teaching mode systematically into the current teaching system is still in the preliminary stage of exploration, unable to clearly explain the core of the whole value chain. In the author's opinion, to conduct a systematic and comprehensive research on talent cultivation and curriculum teaching, the first is to refer to the core value of maker education, that is, the expansion of systematic value-added education, so as to achiever the organic combination with the existing education system; secondly, it is necessary to conduct a systematic analysis based on the research of the environmental design practical teaching mode of the "integrated" educational whole value chain, to go beyond the research stage, which requires to be combined with professional characteristics, Zhejiang University of Finance \& Economics Dongfang College's teaching situation and China's national conditions.

\section{Analysis of the Current Situation of Environmental Design Teaching and the Construction of Reform Mode}

\subsection{Curriculum system and Analysis of Current Teaching Situation}

Established for 17 years, the environmental design major of School of Culture Communication \& Design, with a certain amount of teaching experience, have problems related to insufficient teaching experience due to the relatively young team of professional teachers. Detailed analysis of the school's teaching system will be conducted as below.

After years of teaching exploration, the "platform + module" teaching model have been chosen, which consists of public teaching platform, subject teaching platform, and professional teaching platform [10].

Public teaching platform mainly includes cultural general courses: ideological and political theory, physical quality (physical education), psychological quality (mental health education), basic quality and ability quality (foreign language, computer and basic courses, etc.) [11].

Subject teaching platform are required courses to guide students into professional learning, including three major components, basic design theory, and design software.

Professional teaching courses are mainly courses of the professional teaching module [12]. As extension of the professional teaching platform, these are refined and improved courses on the basis of the environmental art design professional teaching platform, highlighting the systematic and overall nature of the major. Through refined learning in specialized design one (office space design), specialized design two (residential area planning and design), specialized design three (commercial space design), specialized design four (landscape planning and design), comprehensive design, public art design and other courses, students are able to grasp the theoretical knowledge and design procedures and methods.

After 17 years of exploration of the above curriculum system settings, School of Culture Communication \& Design's environmental design major has a reasonable teaching system and a relatively complete curriculum framework; the disadvantage is difficulty in carrying out systematic reforms in integrating the concept and practice of maker education into the classroom based on the integrated education model because of the current teaching system and curriculum settings. At the same time, adhering to the training concept of cultivating senior application-oriented professionals, teachers have always been paying more attention to the training of students' professional skills in the formulation of professional training programs [13]. Decline of students' interest in learning and limit in thinking ability caused by too much emphasis on professional skills training are major problems that we need to tackle in the reform of practical teaching.

\subsection{Analysis of Reform Model Construction}

In view of the above problems, Zhejiang University of Finance \& Economics Dongfang College's environmental design integrated practical teaching reform should be an extension of the original professional education curriculum system to combine theory and practice teaching on the basis of matching; it is necessary to combine traditional teaching mode with digitalization and networking; it is important to expand multidimensional practical education teaching mode, thereby combining the connotation of integrated practical teaching with the needs of social transformation to carry out compound talent training [14]. Based on the above analysis, it can be 
concluded that our reform needs to solve the following three problems from the macro, meso and micro levels:

\subsubsection{A Systematic Hierarchical Study of the Practice Teaching Stages at the Macro Level}

Taking into consideration current teaching status, including the professional practice education situation, problems in school-enterprise cooperation, and the formalization of the maker space, it is necessary to construct a curriculum system centered on "integrated $1+2+2$ " on the basis of matching the original education curriculum system of the major as much as possible. Besides, the professional curriculum education modules should be refined into four levels: basic practical teaching, derivative practical teaching, practical training, and comprehensive practical teaching, with different forms of school-enterprise cooperative practice teaching introduced into different levels of practice teaching, thus forming a inter-connected and step-by-step teaching system with clear distinct layers [15].

\subsubsection{Exploration and Reconstruction of the Professional Practical Teaching Mode at the Mesoscopic Level}

To solve problems of inertia of professional teaching, single teaching methods, and waste of online teaching resources, the traditional teaching methods can be reformed through information technology and big data network platforms to construct a "network + classroom" model; on the other hand, through "theory + practice" classroom model, it is important to emphasize the deep participation of learning in creation to improve students' independent learning and innovative practical ability.

\subsubsection{Cultivation of Students' Complex Practical Ability of "Integration with Craftsmanship" at the Micro Level}

In accordance with China's demand for design talents, the reform will guide practical education out of the instrumentalism and strengthen the breadth of knowledge and the complexity of skills, so as to improve students' practical ability to solve problems; Second, to explore the transformation of practical education, it is important to pay attention to the refined distribution of practical tasks and the diversified methods of knowledge verification to meet social needs.

\section{Research on the Integrated Practical Teaching Mode of Environmental Design}

\subsection{Establishment of a Practical Curriculum System Centered on "Integrated 1+2+2"}

Based on the original training plan for students entered the university in 2017 of the environmental design major, the "integrated $1+2+2$ " practical curriculum system has been made a preliminary conception (Table 1) with details as follows, including students' acceptance of the curriculum system, the actual teaching situation of the major, and analysis of the online and offline questionnaires of current students and graduates:

Table 1. "Integrated 1+2+2" practice course stage schedule.

\begin{tabular}{|c|c|c|c|c|}
\hline \multicolumn{5}{|c|}{ "Integrated 1+2+2" practice course stage schedule } \\
\hline \multirow{4}{*}{$\begin{array}{l}\text { Skill } \\
\text { requirements }\end{array}$} & 1: Basic practical teaching & 2: Derivative practical teaching & & $\begin{array}{l}\text { 2: Innovative practice training }+ \\
\text { comprehensive practice }\end{array}$ \\
\hline & The first grade & The second grade & The third grade & The fourth grade \\
\hline & Subject foundation & Subject foundation & Subject foundation & Subject foundation \\
\hline & + cognitive practice & + cognitive practice & + cognitive practice & + cognitive practice \\
\hline $\begin{array}{l}\text { Specific } \\
\text { courses }\end{array}$ & Freshman Basic Courses & $\begin{array}{l}\text { Sophomore professional basic } \\
\text { courses Sophomore professional } \\
\text { courses }\end{array}$ & $\begin{array}{l}\text { Junior professional courses } \\
\text { Derivative practice courses }\end{array}$ & $\begin{array}{l}\text { Comprehensive practical course for the } \\
\text { fourth stage } \\
\text { Innovation and entrepreneurship } \\
\text { practice course }\end{array}$ \\
\hline \multirow{2}{*}{$\begin{array}{l}\text { Teaching } \\
\text { practice }\end{array}$} & $\begin{array}{l}\text { Enterprise industry culture } \\
\text { introduction }\end{array}$ & $\begin{array}{l}\text { Professional teachers and industry } \\
\text { experts enter the classroom }\end{array}$ & $\begin{array}{l}\text { Practice projects in the } \\
\text { classroom }\end{array}$ & $\begin{array}{l}\text { Graduation project } \\
\text { Innovation and entrepreneurship } \\
\text { special training }\end{array}$ \\
\hline & Industry introduction lecture & Experiential professional practice & $\begin{array}{l}\text { Integrated/innovative } \\
\text { professional classroom }\end{array}$ & $\begin{array}{l}\text { Comprehensive practice of innovation } \\
\text { and entrepreneurship }\end{array}$ \\
\hline $\begin{array}{l}\text { teaching } \\
\text { objectives }\end{array}$ & $\begin{array}{l}\text { Combination of general } \\
\text { knowledge education in } \\
\text { professional industry and } \\
\text { professional skills education }\end{array}$ & $\begin{array}{l}\text { Combination of professional core } \\
\text { knowledge and skills with the } \\
\text { actual needs of professional } \\
\text { teachers }\end{array}$ & $\begin{array}{l}\text { Combination of professional } \\
\text { core competence training } \\
\text { and enterprise innovation } \\
\text { practice }\end{array}$ & $\begin{array}{l}\text { Close integration of the cooperative } \\
\text { guidance of school and enterprises and } \\
\text { talent output }\end{array}$ \\
\hline
\end{tabular}

"1": Freshmen should pay attention to basic practical teaching; the curriculum is generalized and a shared course platform is established to cultivate students' awareness to recognize and solve problems; in addition to professional skills, industry culture introduction courses are arranged to develop students' industry general knowledge as well.

"2": Derivative practical teaching is conducted in the second and third grades; in the sophomore stage, industries, enterprises, and guest professors are introduced into the classroom while in the third stage real design projects are implanted; the sophomore professional core knowledge and skills are combined with actual social needs and the third year's professional core competence training is combined with the actual work of enterprise projects, so as to cultivate students' practical innovation ability and macro-humanistic literacy from an integrative and innovative perspective.

"2": Innovative practice training + comprehensive practice is applied in the fourth grade: for students in the senior stage, social and corporate resources are used to lead students to practice and pay attention to emerging social issues, thereby improving their practical problem handling capabilities. This model emphasizes the cooperative guidance of school and corporate mentors and the close integration of the school and enterprises to achieve a three-dimensional and progressive combination of practice and teaching. 


\subsection{Extension and Reconstruction of Practical Teaching Mode}

\subsubsection{The Form of "Network + Classroom" Practice Teaching}

First, based on platforms such as "Internet +" and big data, the traditional teaching mode is combined with digitization and networking to expand new forms of network practice. In professional teaching, professional interactive software can be combined: for indoor design, intelligent software such as Digital China, Yiqixiu, Kujiale, Whole Home, Love Space, Youzhu Network, etc. can be combined [3]; for landscape planning design, VR technology, GIS Space syntax, Baidu map, VR technology and powerful cloud design platform can be used to build field survey data.
In the post-epidemic era, based on the virtual reality environmental investigations, teachers can conduct "situational, project-based, and experiential" practical teaching that meets professional characteristics through network simulation, so that students can gain in-depth understanding of topography and environmental characteristics through sensory experience from data and images, so as to achieve the teaching purpose of derivative practice. The following is the "classroom + network platform" practical teaching course analysis table (Table 2). Through the reasonable development and utilization of network resources, it is possible to break through the barriers in the teaching of practical courses in the major and to explore the new practical teaching mode of "network practice + classroom".

Table 2. "The "classroom + network platform" practice teaching course analysis table (drawn by the author).

\begin{tabular}{|c|c|c|c|c|}
\hline Specific courses & Preliminary interior design & Material and technology & Specialized Design (2) & Specialized Design (4) \\
\hline $\begin{array}{l}\text { Practical } \\
\text { teaching } \\
\text { resources }\end{array}$ & $\begin{array}{l}\text { The use of CAD, SU, Kujiale, } \\
\text { VRAY software and other } \\
\text { network platform }\end{array}$ & $\begin{array}{l}\text { The use of software and big } \\
\text { data platforms such as CAD, } \\
\text { SU, PS, VRAY, Yiqixiu, } \\
\text { Kujiale, and Whole Home }\end{array}$ & $\begin{array}{l}\text { The use of MARS to realize } \\
\text { online VR space research and } \\
\text { plan production }\end{array}$ & $\begin{array}{l}\text { The use of VR technology, } \\
\text { combined with GOOGLE Maps, } \\
\text { Baidu Maps, especially Street } \\
\text { View Map functions }\end{array}$ \\
\hline $\begin{array}{l}\text { Practical } \\
\text { teaching goals }\end{array}$ & $\begin{array}{l}\text { Familiar with the basic use of } \\
\text { CAD to draw indoor plan and } \\
\text { elevation drawings. } \\
\text { Proficiency in using PS to } \\
\text { make color elevations. } \\
\text { Mastering the modeling and } \\
\text { design of indoor models } \\
\text { through network design } \\
\text { platforms such as Kujiale. } \\
\text { Proficiency in using VRAY to } \\
\text { independently complete the } \\
\text { indoor modeling and rendering } \\
\text { process and optimizing models } \\
\text { with PS. }\end{array}$ & $\begin{array}{l}\text { Ability to independently } \\
\text { complete the reading and } \\
\text { drawing of indoor construction } \\
\text { drawings, and understand the } \\
\text { characteristics of indoor hard } \\
\text { decoration materials and } \\
\text { construction technology. } \\
\text { Ability to complete material } \\
\text { analysis and process evaluation } \\
\text { in combination with the } \\
\text { project; Ability to complete } \\
\text { design drawings, renderings, } \\
\text { and corresponding node } \\
\text { construction drawings. }\end{array}$ & $\begin{array}{l}\text { Ability to complete the survey } \\
\text { and report with the use of } \\
\text { multi-dimensional and } \\
\text { interactive MARS software. In } \\
\text { the era of big data, it is necessary } \\
\text { to realize the "cloud research" } \\
\text { technology in the classroom, so } \\
\text { as to realize the integrated } \\
\text { multi-dimensional scene } \\
\text { experience, and meet the needs } \\
\text { of remote communication } \\
\text { between student groups and } \\
\text { online program discussion with } \\
\text { Party A. }\end{array}$ & $\begin{array}{l}\text { The ability to use VR technology, } \\
\text { GOOGLE Maps, Baidu Maps and } \\
\text { other software to complete } \\
\text { research and reporting. Ability to } \\
\text { clarify the current situation of the } \\
\text { project location, extract elements } \\
\text { such as transportation and } \\
\text { functions; and complete the } \\
\text { analysis of natural climate and } \\
\text { plant configuration, so as to meet } \\
\text { the needs of practical investigation } \\
\text { during classroom teaching and } \\
\text { provide materials for the design of } \\
\text { space nodes. }\end{array}$ \\
\hline
\end{tabular}

Secondly, with networked practical teaching as the core, distance teaching mechanism, teaching staff, and teaching resource sharing as the foundation [16], and the "virtual project context", diversified practice mode, and school-enterprise interaction used, an art "online" interactive practical teaching and research platform is established, further perfecting the widely disseminated multimedia "online" course system.

Based on the above analysis, the author took the preliminary course of landscape design as an example to conduct a detailed analysis of course knowledge, teaching resources, teaching goals, and teaching methods (Figure 1).

\subsubsection{The Construction of a New Model of "Knowledge and Practice" Classroom Teaching}

Combining various teaching methods including system analysis teaching, project teaching, flipped classrooms, mobile terminal teaching, etc., the model emphasizes the deep participation of "learning in creation", thereby enhancing students' practical learning and independent innovation capabilities while improving the quality of teaching [17].

First, the organic combination of system analysis and project teaching (Figure 2)

From the perspective of maker education, systematic training analysis combines heuristic teaching, case teaching, task-driven teaching, situational teaching, experimental cognitive teaching and other teaching methods to realize the combination of knowledge and practice. Taking into consideration the characteristic of systematic analysis which uses qualitative and quantitative tools to systematically sort out the problems studied in practice and "project teaching" of the environmental design major, the author systematically sorted out the existing teaching methods and summarized the following procedure, that is, pre-project investigation and explanation $\rightarrow$ problem determination $\rightarrow$ goal seeking $\rightarrow$ theoretical explanation $\rightarrow$ analysis and evaluation through big data platform system plan proposals for advantages and disadvantages $\rightarrow$ comparative analysis $\rightarrow$ guidance for students to think and evaluate. The advantage of this teaching method is that it, fully considering the thinking style and professional characteristics of environmental design students, gradually impart knowledge and conduct practical training, which is conducive to developing students' multi-dimensional thinking and practical application ability. The details are shown in the figure: 


\section{"Preliminary Landscape Design" Network Classroom Teaching Arrangement}

\begin{tabular}{|c|c|c|c|c|}
\hline \multirow{2}{*}{$\begin{array}{l}\text { skill } \\
\text { requirem } \\
\text { ents }\end{array}$} & Week 1 & Week 2 & Week 3 & Week 4 \\
\hline & $\begin{array}{l}\text { Subject foundation }+ \\
\text { theoretical } \\
\text { explanation }+ \\
\text { cognitive practice }\end{array}$ & $\begin{array}{l}\text { Professional core }+ \\
\text { program explanation }+ \\
\text { program practice }\end{array}$ & $\begin{array}{l}\text { Professional core }+ \\
\text { plan deliberation }+ \\
\text { design practice }\end{array}$ & $\begin{array}{l}\text { Professional } \\
\text { practice }+ \text { scheme } \\
\text { refinement }+ \text { Project } \\
\text { reporting }\end{array}$ \\
\hline \multirow{2}{*}{$\begin{array}{l}\text { Teaching } \\
\text { arrangem } \\
\text { ents and } \\
\text { teaching } \\
\text { resources }\end{array}$} & $\begin{array}{l}\text { Teaching of } \\
\text { theoretical } \\
\text { knowledge, } \\
\text { mainly by } \\
\text { instructors }\end{array}$ & $\begin{array}{l}\text { Design plan explanation: } \\
\text { Professional teachers } \\
\text { and industry experts } \\
\text { enter the classroom }\end{array}$ & $\begin{array}{l}\text { Design plan } \\
\text { deliberation: } \\
\text { Instructor + Student } \\
\text { Discussion }\end{array}$ & $\begin{array}{l}\text { Design report: } \\
\text { Professional } \\
\text { teachers and } \\
\text { industry experts } \\
\text { enter the classroom }\end{array}$ \\
\hline & $\begin{array}{l}\text { Teaching } \\
\text { courseware + } \\
\text { sharing network } \\
\text { resources: } \\
\text { MOOC for Chinese } \\
\text { college students } \\
\text { (Principles of } \\
\text { Landscape } \\
\text { Architecture Design, } \\
\text { Western Landscape } \\
\text { Architecture Art } \\
\text { History, etc.) + } \\
\text { various learning } \\
\text { websites + BILIBILI } \\
\text { website + GOOGLE } \\
\text { map + Baidu map }\end{array}$ & $\begin{array}{l}\text { Student report + teacher } \\
\text { comment + sharing big } \\
\text { data network resources: } \\
\text { GIS spatial syntax: } \\
\text { understand the urban } \\
\text { layout texture, and } \\
\text { conduct a large spatial } \\
\text { layout analysis } \\
\text { Google Maps/Baidu } \\
\text { Maps: Through precise } \\
\text { positioning of two- } \\
\text { dimensional and three- } \\
\text { dimensional maps, } \\
\text { understanding the } \\
\text { details and project site } \\
\text { photos }\end{array}$ & $\begin{array}{l}\text { Teachers' explanation } \\
\text { + student discussion + } \\
\text { targeted explanation } \\
\text { of network resources: } \\
\text { Chinese college } \\
\text { students' MOOC } \\
\text { (spatial art of the } \\
\text { Dream of Red } \\
\text { Mansions, Western } \\
\text { garden landscape } \\
\text { renderings, etc.) + } \\
\text { various learning } \\
\text { websites + BILIBILI } \\
\text { website + GOOGLE } \\
\text { map + Baidu map }\end{array}$ & $\begin{array}{l}\text { Teachers' } \\
\text { explanation + expert } \\
\text { comment + student } \\
\text { interactive } \\
\text { discussion + expert } \\
\text { sharing real projects } \\
\text { and cases, with } \\
\text { comments in the } \\
\text { form of web } \\
\text { conference }\end{array}$ \\
\hline $\begin{array}{l}\text { Teaching } \\
\text { objectives }\end{array}$ & $\begin{array}{l}\text { Combination of } \\
\text { general knowledge } \\
\text { education in } \\
\text { professional } \\
\text { industry and } \\
\text { professional skills } \\
\text { education }\end{array}$ & $\begin{array}{l}\text { Combination of } \\
\text { professional core } \\
\text { knowledge and skills } \\
\text { with the actual needs of } \\
\text { professional teachers }\end{array}$ & $\begin{array}{l}\text { Combination of } \\
\text { professional core } \\
\text { competence training } \\
\text { and practical } \\
\text { application }\end{array}$ & $\begin{array}{l}\text { Close integration of } \\
\text { the cooperative } \\
\text { guidance of school } \\
\text { and enterprises and } \\
\text { talent output }\end{array}$ \\
\hline
\end{tabular}

Figure 1. Preliminary Landscape Design “Network + Classroom” Teaching Arrangement (drawn by the author).

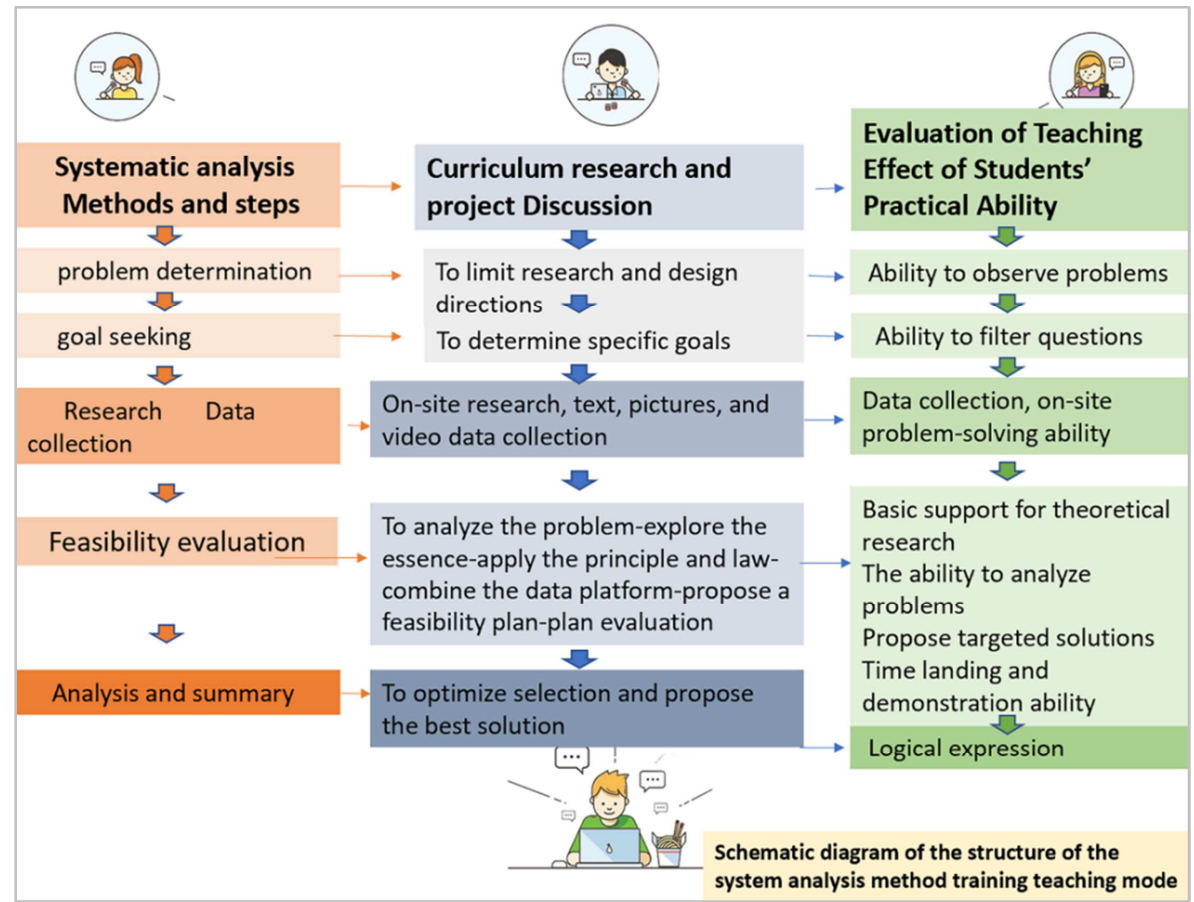

Figure 2. Analysis diagram of course teaching based on system analysis (drawn by the author).

Second, the flipped classroom teaching model combines "learning in practicing" and "learning by practicing".
The flipped classroom in design major can be developed in five steps, that is, curriculum development, learning guidance, 
knowledge application, practical feedback, and refinement and sublimation [18]. Students can acquire relevant knowledge and information both inside and outside the classroom with the help of diversified network data and platforms. A flipped classroom teaching model refers to carrying out teamwork and active interaction between teachers and students to build a good theory and practice collaborative learning environment, implementing the integrated and experienced practical courses in different stages, and integrating practice and theory learning into the teaching process.

\subsubsection{Cultivation of Students' Complex Practical Ability of "Integration with Craftsmanship"}

Different from the traditional practical education, it strengthens the breadth of knowledge and the complexity of skills, encouraging students to participate in the process of practice with creative thinking [2]. At the same time, in accordance with the actual needs of design talents, in the teaching process, the practical tasks are finely distributed and diversified knowledge inspection methods are introduced according to the development needs of the industry. The specific implementation can be divided into the following three steps:

The first is to expand cross-professional software learning and strengthen the complexity of knowledge and skills. In addition to the traditional major software for environmental design such as AutoCAD, Adobe phtoshop, Sketch-up, and Autodesk 3dmax, Adobe Illustrator, Luminous, Painter, Adobe Flash, Adobe Premiere, Rhino3D NURBS, Auto desk Revit, Adobe InDesign and other related design software skills are also required to grasp [3].

Secondly, in the era of big data, it is also necessary to flexibly use Internet interactive software such as Kujiale, Whole Home, Datalink China, and Yiqixiu. On the one hand, students can use professional practice software and big data platform to deepen their professional knowledge and skills; on the other hand, students can develop a targeted understanding of the development trend of professional industries and carry out practice to expand their innovation and entrepreneurship practice platforms after learning.

\subsubsection{Landing Transformation of Practical Education, Refined Assignment of Practical Tasks, and Diversified Methods of Knowledge Verification}

This is mainly the update and reform of the assessment mechanism. Based on the traditional performance evaluation method, that is, the final score is scored by the usual scores, weekly homework grades, and the final submitted homework text, to refine the requirements of practical innovation ability, which includes five aspects: basic design ability, design application ability, language expression ability, comprehensive planning ability and design management ability according to the goal of compound talent cultivation in environmental design. Based on big data research, the five aspects of design application capabilities are divided into different proportions, of which basic design capabilities account for $30 \%$, design application capabilities $40 \%$, language expression capabilities 10\%, comprehensive planning capabilities $10 \%$, and design management ability $10 \%$ [3]. In terms of this, it is planned to refine the knowledge of the curriculum and finely distribute practical work to improve the teaching quality.

What's more, the abilities mentioned above are not completely independent. In the process of teaching and training, comprehensive ability from multiple directions and angles is developed.

Design basic ability + language expression ability: To solve passive learning of students and passive teaching of teachers, the teaching tasks are finely arranged. In order to effectively understand the professional learning situation of students, students are required to write reading notes after the class. Besides, during classes, students are required to share the learning experience of course cases and professional skills, which will force students to conduct detailed and in-depth research on the content of the course at each stage.

Design management ability + design application ability: for students' classroom sharing content, teachers can organize targeted, adaptable and practical cases in subsequent courses for comparative analysis and teaching through efficient collection of students' knowledge mastery to realize the flipped teaching of theory + practice.

Design ability + comprehensive planning ability + design management ability: The content of design practice courses is refined according to the stages of investigation and analysis, project planning, problem solving, project reporting and modification, with students' understanding and mastery of skills and professional knowledge at different stages taken into consideration.

Design application ability + language expression ability + comprehensive planning ability + design management ability: In the project reporting stage, in addition to the traditional plan report summary method, it can also, breaking the transportation geographical restrictions, invite external experts and corporate mentors to participate in the project assessment to jointly create an art online interactive practice teaching and research and innovation platform through virtual project situation, network video conferences, and school-enterprise interaction, thereby mobilizing students' enthusiasm for learning.

\section{Conclusion}

Aiming at Zhejiang University of Finance \& Economics Dongfang College's not deep enough curriculum practice innovation content, insufficient teaching philosophy and student practice model which can not fully adapt to the development of the times, the environmental design practice teaching reform discussed in the text strives to combine the traditional teaching mode with digitalization and networking to expand the multi-dimensional practical teaching mode based on the construction of "integrated" educational whole value chain practical teaching. Th reform emphasizes practical theory learning to reflect the teaching process and hands-on practice to verify the "theory + practice" teaching concept. In 
this way, it transforms the connotation of integrated practical teaching into value-added education of knowledge and skills with practical teaching training goals throughout daily life study, showing a trend to integrate practical education into the whole process of university talent cultivation.

\section{Acknowledgements}

This work is supported by four programs : (1) Higher Education Research Project of Zhejiang Higher Education Association 2020(NO.: KT2020203) ; (2) Zhejiang University of Finance \& Economics Dongfang College The first batch of industrial colleges, industry and education integration demonstration base construction projects(NO.: 122276213107); (3) Zhejiang University of Finance \& Economics Dongfang College a Major Program of the Key Higher Education Teaching Reform Project, Cooperated Industry-University-Research Application: Studies on Progressive Talent Training Mode(NO.: 2019JK03); (4) Zhejiang University of Finance \& Economics Dongfang College a Major Program of Special Design : Exploration and Practice of Practical Teaching. (NO.: 2019JK46).

\section{References}

[1] Li Xiaoyan: Research on the reform of applied talents training model in colleges and universities - The perspective of serving local economic development [J], 2018, 23 (02): 138-141.

[2] Wang Youmei: Review on the Theoretical Thinking of Current Maker Education Practice in Chinese Universities [J], 2017 (04): $20-31+87$.

[3] Qi Yancheng, Ma Mnegyun: Research on Teaching mode of college students' innovation and entrepreneurship in environmental design under the background of "Internet + " $[\mathrm{J}]$, 2018 (11): 71-72.

[4] Yu Changliang: The Development of Maker Education in Vocational Colleges of "Internet+" [J], 2018, 39 (06): 99-103.

[5] Su Hongwei, Tang Xingfang: Advancing Paradigm Shift_-From Carrying out Innovation and Entrepreneurship
Education Reform to Setting up the Innovation and Internship Education Specialty [J], 2017 (03): 8-12.

[6] Zhu Zhiting, Sun Yanyan: Maker Education: a Practical Field of ICT-Enabling Innovation Education [J], 2015 (1): 14-21.

[7] Hu Jiliang: A Primary Probe into the Evaluation System of College Students' Scientific and Technological Innovation Based on the Maker Project of College Students [J], 2017 (03): 71-73.

[8] Su Yuanhua: Research on the Arduino course design for STEM Project Based Learning [D], 2017.5.

[9] Sun Qiu: Reform and Practice of Public Computer Basic Teaching in Engineering Colleges Based on the Concept of CDIO [J], 2011 (01): 153-154.

[10] Tang Yinguo: On the Curriculum Reform and Construction of Newly-built Undergraduate Colleges [J], 2010, 17 (03): 96-99.

[11] Sun Jie: Survey of Current College Students' Values [J], 2011 (02): 1-3.

[12] Jiang Hong: Research on Optimization of Course Content System of "Air Transport Geography" Based on Professional Needs [J], 2016 (06): 15-16.

[13] Xu Zhongrong: Research on the Reform of the Training Model of Applied Innovation Talents in Economic Management Majors-Taking Suqian University as an Example [J], 2010 (14): 83-85.

[14] Ai Jumei, Lu Ling: The establishment and application of collaborative network teaching platform [J], 2007 (11): 125.

[15] Wang Caiping: Research on the Integrated Practice Teaching System of Chinese Universities, 2010.7.

[16] Chen Yanping, Wang Zhongmin, Sun Hanlin, Niu Xiaochen, Shu Xinfeng: On Practical Teaching Resource Quality Monitoring Model [J]., 2016, 35 (01): 102-105.

[17] Liu Lei: practical exploration of Exemplary teaching in current junior middle school chemistry teaching [J], 2016 (09): 12 .

[18] Zhou Chuyi: The Cultivation of Design Creativity in "Flipped Classroom" [J], 2017 (16): 115-117. 